\title{
Primary care-based educational interventions to decrease risk factors for metabolic syndrome for adults with major psychotic and/or affective disorders: a systematic review
}

\author{
Cynthia Nover ${ }^{1 *}$ and Sarah S Jackson ${ }^{2}$
}

\begin{abstract}
Background: Individuals with major psychotic and/or affective disorders are at increased risk for developing metabolic syndrome due to lifestyle- and treatment-related factors. Numerous pharmacological and non-pharmacological interventions have been tested in inpatient and outpatient mental health settings to decrease these risk factors. This review focuses on primary care-based non-pharmacological (educational or behavioral) interventions to decrease metabolic syndrome risk factors in adults with major psychotic and/or affective disorders.
\end{abstract}

Methods: The authors conducted database searches of PsychINFO, MEDLINE and the Cochrane Database of Systematic Reviews, as well as manual searches and gray literature searches to identify included studies.

Results: The authors were unable to identify any studies meeting a priori inclusion criteria because there were no primary care-based studies.

Conclusions: This review was unable to demonstrate effectiveness of educational interventions in primary care. Interventions to decrease metabolic syndrome risk have been demonstrated to be effective in mental health and other outpatient settings. The prevalence of mental illness in primary care settings warrants similar interventions to improve health outcomes for this population.

Keywords: Metabolic syndrome, Serious mental illness, Primary care, Weight loss, Schizophrenia, Schizoaffective, Bipolar, Major depressive disorder, Physical health intervention, Educational intervention, Behavioral intervention

\section{Background}

Comorbidity of mental illness and chronic physical illness Individuals with major psychotic and/or affective disorders (for example, schizophrenia, bipolar disorder or major depressive disorder) experience higher rates of comorbid physical health problems compared with the general population. Cardiovascular risk and metabolic risk are increased in individuals with schizophrenia [1-3] and depression $[4,5]$. Bipolar disorder has also been shown to be associated with metabolic syndrome [6,7]. Risk factors for cardiovascular disease and metabolic syndrome include: high blood pressure, large waist circumference, high triglyceride

\footnotetext{
* Correspondence: cnover@ewu.edu

${ }^{1}$ College of Social \& Behavioral Sciences and Social Work, Eastern Washington University, 208 Senior Hall, Cheney, WA 99004, USA
} Full list of author information is available at the end of the article levels, low HDL cholesterol level, and high fasting blood sugar levels.

Causes of comorbidity in this population are thought to include psychiatric medication and lifestyle factors, such as diet and tobacco consumption. Atypical antipsychotic medication (AAP), commonly prescribed for patients with bipolar disorder or schizophrenia, increases risk for metabolic syndrome [8-10]. Individuals with major psychotic disorders, especially schizophrenic disorders, also consume tobacco at higher rates than the general population [1,11-13], which partially explains the increased risk of cardiovascular disease in this population. Bobes et al. [1] found that tobacco users with major psychotic or affective/ mood disorders were more likely to consume daily alcohol and caffeine and less likely to avoid salt and saturated fats. Sedentary lifestyle and unhealthy food consumption 
patterns, including higher daily intake of calories and cholesterol, are common among individuals with major psychotic and/or affective disorders [11,14].

\section{Previous interventions tested}

Many interventions intended to decrease risk factors for metabolic syndrome, both pharmacological and nonpharmacological, have been tested and described in the literature. Systematic reviews and meta-analyses of interventions to control risk factors for metabolic syndrome [15-23] indicate that both pharmacological and nonpharmacological (that is, behavioral or educational) interventions can be effective in decreasing metabolic risk. The studies described in these systematic reviews generally take place in mental health settings, which may exclude those individuals with mental illness who receive treatment primarily in the primary care setting. Only one study included in these reviews [24] features a primary carebased intervention. Previous weight loss interventions conducted in the primary care setting have demonstrated efficacy in many populations [25-29].

\section{Mental illness in primary care}

Individuals with major psychotic or affective/mood disorders who are not psychiatrically hospitalized are generally treated for physical and sometimes mental health disorders in primary care settings in the U.S. due to a lack of integrated medical and behavioral health programs. Several studies in the U.S. and elsewhere have noted the prevalence of major psychotic or affective/mood disorders in the primary care setting. Serrano-Blanco et al. [30] conducted a study with over 3,800 primary care patients and found that $29.9 \%$ had a diagnosis of major depressive disorder. Das et al. [31] screened 1,157 primary care patients and found that approximately $10 \%$ met diagnostic criteria for bipolar disorder. Blount [32] reported that $80 \%$ of individuals with a mental health disorder will see their primary care physician in a given year, while only $50 \%$ will see a mental health provider. Roca et al. [33] reported on a similar study of more than 7,900 primary care patients and found that $29 \%$ of patients had been diagnosed with major depressive disorder. Fernandez et al. [34] conducted a cross-sectional study in primary care and found that mood disorders are the second leading cause of qualityadjusted life years in the primary care setting. The loss of quality of life and prevalence of psychiatric disorders in primary care demonstrates a need for primary-care based interventions to decrease chronic comorbid conditions.

\section{Objectives of review}

The prevalence of psychiatric disorders in primary care settings and the association between chronic mental and physical illness necessitates an exploration of primary carebased interventions to address these comorbid conditions.
This review focuses on non-pharmacological, educationbased interventions to address metabolic syndrome risk factors in patients with major psychotic or affective/ mood disorders who are treated in the primary care setting. The emphasis is on metabolic syndrome risk factors because this combination of risk factors can lead to chronic illnesses and early mortality in this population [35]. Education-based interventions are important because they empower the patient to manage his/her illness independently and expand the role of social workers in the primary care setting. According to Michie, Fixsen, Grimshaw and Eccles [36], systematic reviews of behavior change interventions typically produce modest effects. The primary author was involved in a primary care-based complex intervention to improve metabolic risk factors among patients with major psychotic and/or affective/ mood disorders and patient reports indicated that they found the educational components most beneficial for self-management of illnesses [37].

\section{Methods}

Literature search

Electronic searches were conducted using MEDLINE, PsychINFO and the trials registry of the Cochrane Database of Systematic Reviews. The abstracts, titles and index terms of studies were searched in MEDLINE and PsychINFO using the following keywords: "schizophreni*" OR "schizoaffective" OR "bipolar" OR "major depressive disorder" OR "posttraumatic stress disorder" OR "serious mental illness" AND "metabolic syndrome" OR "high blood pressure" OR "triglycerides" OR "cholesterol" OR "HDL" OR "waist circumference" OR "blood sugar" OR "blood glucose" AND "intervention" OR "randomized controlled trial" OR "quasi-randomized" AND "primary care." All titles in the Cochrane Schizophrenia Register were scanned for possible inclusion. Additionally, manual searches were conducted using references from literature found in the database search.

\section{Eligibility assessment}

\section{Inclusion and exclusion criteria}

Studies were included if the population studied met the following criteria: adults ages 18 or older; diagnosed with one of the five mental illnesses which typically constitute major psychotic and/or affective disorders (schizophrenia (DSM-V code 295.9), schizoaffective disorder (DSM$\mathrm{V}$ code 295.7), major depressive disorder (DSM-V code 296.3), or bipolar disorder (DSM-V codes 296.4 and 296.5)); and had risk factors for metabolic syndrome, including large waistline, a high triglyceride level, a low HDL cholesterol level, high blood pressure, and high fasting blood sugar level. The study setting must have been in a primary care location. The study design must have been either a randomized controlled trial (RCT) or 
a quasi-experimental study. Study outcomes must include one of the risk factors for metabolic syndrome (for example, blood pressure, waist circumference, triglyceride levels, blood glucose or (an increase in) HDL).

Studies were excluded if:

- the population studied was younger than 18 years old or did not have a diagnosis of a major psychotic and/or affective disorders or risk factors for metabolic syndrome;

- they were conducted in an inpatient or mental health-based setting;

- they were not an RCT or quasi-experimental study, and

- the outcome of the study did not include one of the risk factors for metabolic syndrome.

\section{Results}

Our initial systematic search of databases MEDLINE and PsychINFO (which was not limited by setting) yielded 316 results. When "primary care" was added to the search, we found 19 additional results. A title search of the Cochrane Database of Systematic Reviews resulted in the identification of two systematic reviews; one review had no included studies and the other had six studies included in the quantitative synthesis. These studies were also identified in database searches and are part of the 363 total studies identified below. Manual searches from reference lists of articles found in the database search were conducted and 90 studies were found. A search of gray literature was conducted to decrease risk of publication bias using Open Grey (www.opengrey.eu) with the same MESH terms, but no additional studies were found. A total of 363 unique studies were found from the collection of searches after duplicates were removed. The titles of all 363 of these results were reviewed separately by each reviewer and 303 were excluded based on setting or nature of intervention. There were no disagreements during this process. The remaining 60 articles were reviewed in abstract and 30 were excluded based on study design or setting. Full-text reviews were conducted by both reviewers $\mathrm{CN}$ and $\mathrm{SJ}$ for the remaining 30 of the studies and reviewers agreed that no studies met inclusion criteria; all studies were excluded. Additional file 1 provides a diagram of how studies were excluded. Table 1 lists all of the studies reviewed in full-text from database searches and manual searches with reasons for exclusion.

Through the manual search, 13 systematic reviews were identified for further review of citations. Table 2 provides a list of the 13 systematic reviews. These reviews examined a total of 221 studies. Raters $\mathrm{CN}$ and SJ independently screened titles or abstracts from these studies and all 221 studies were rejected for not meeting the inclusion criteria.

\section{Discussion}

Although we identified no studies that met the a priori inclusion criteria, there were 16 studies identified during database and manual searches that examined similar interventions in non-primary care settings. These studies (listed in Table 3) demonstrate that controlled trials with education interventions to improve physical health can be conducted with individuals with major psychotic and/ or affective disorders; the systematic reviews shown in Table 2 indicate that these interventions can be effective. Also, it should be recognized that no evidence of effective primary care-based studies does not mean that such intervention is ineffective; further studies are needed in this area to determine whether such interventions can be effective in primary care settings.

Of the 16 similar studies of educational interventions, reviewers identified 6 studies that may be able to be implemented in the primary care setting [42,51,53,56,63,65]. Those studies of interventions that might not be appropriate for primary care include interventions that were too long $[45,47,61]$, provided products or services that might not be available in primary care settings $[43,48,55,62,71]$ or required patients to have not yet developed physical risk factors prior to the intervention [46].

An examination and discussion of the details of the interventional components of the studies possible in primary care identified in Table 3 is warranted here, because future studies in the primary care setting must adequately describe their interventions in order to be replicated or subject to systematic review. The methodological quality of these studies is summarized in Table 4. All of these studies provided explicit descriptions of the intervention components; McKibbin et al. [56], Weber and Wyne [65] and Kwon et al. [53] also described session-by-session content of the intervention in table and narrative format; Brar et al. [42] described sessions in narrative format only. Khazaal et al. [51] used an intervention previously developed by one of the authors, so readers can review that intervention in detail elsewhere, but it was not described in detail in the article. Srkinar et al. [63] provided a description of the length of the educational intervention and a list of topics, but no sequence or table of sessions was provided. All studies identified as possible in primary care included an intervention element that was not education (or example, food tasting, exercise sessions, provision of pedometers), so the effectiveness of the educational component alone may not be able to be determined from these studies; however, complex interventions are very common in behavioral health research [72]. 
Table 1 Studies reviewed in full-text

\begin{tabular}{|c|c|}
\hline Authors, year & Reason for exclusion \\
\hline Alvarez-Jiminez et al., [38] & Partially pharmacological intervention, mix of different settings (including primary care). \\
\hline Attux, Martini, de Araujo, Roma, Reis and Bressan, [39] & Not RCT; not primary care (mental health services) \\
\hline Ball, Coons and Buchanan, [40] & Not primary care (both arms from outpatient MH services); not randomized \\
\hline Bradshaw, Lovell and Harris, [41] & Not an RCT, not primary care \\
\hline Brar et al., [42] & Not primary care \\
\hline Brown, Goetz, Van Sciver, Sullivan and Hamera, [43] & Not primary care \\
\hline Centorrino et al., [44] & Not primary care; no control group \\
\hline Chafetz, White, Collins-Bride, Cooper and Nickens, [45] & Not primary care \\
\hline Druss, Rohrbaugh, Levinson and Rosenheck, [24] & Wrong outcome \\
\hline Evans, Newton and Higgins, [46] & Not primary care \\
\hline Fosberg, Bjorkman, Sandman and Sandlund, [47] & Not primary care \\
\hline Jean-Baptiste et al., [48] & Not primary care \\
\hline Jones, Basson, Walker, Crawford and Kinon, [49] & Pharmacological intervention \\
\hline Kalarchian et al., [50] & Not an RCT, not primary care \\
\hline Khazaal et al., [51] & Not primary care \\
\hline Kilbourne et al., [52] & Not primary care; outcome not physical health \\
\hline Kwon et al., [53] & Not primary care \\
\hline Littrell, Hilligoss, Kirshner, Petty and Johnson, [54] & Not primary care, partially pharmacological \\
\hline Mauri et al., [55] & Not primary care \\
\hline McKibbin et al., [56] & Not primary care \\
\hline Ohlson, Treasure and Pilowsky, [57] & Not RCT; not primary care \\
\hline Park, Usher and Foster, [58] & Review paper \\
\hline Pendlebury, Bushe, Wildgust and Holt, [59] & Not primary care, no control group \\
\hline Perlman et al., [60] & Not RCT; not primary care \\
\hline Poulin et al., [61] & Not primary care \\
\hline Rotatori, Fox and Wicks, [62] & Not primary care \\
\hline Skrinar, Huxley, Hutchinson, Menninger and Glew, [63] & Not primary care \\
\hline Vreeland et al., [64] & Not primary care, not randomized \\
\hline Weber and Wyne, [65] & Not primary care \\
\hline Weber and Nelson, [66] & Not RCT; not primary care \\
\hline
\end{tabular}

Missing from the descriptions of many articles reviewed in this study were details about who implemented an intervention and where it took place. A number of studies stated that participants were recruited from a certain hospital or facility (for example, Khazaal et al. [51] and Skrinar et al. [63], but it was not clear from the articles whether the actual educational intervention took place in the hospital or in an outpatient setting. Of the studies identified as possible in primary care, only Khazaal et al. [51], Kwon et al. [53] and Weber and Wyne [65] provided a clear description of who was implementing the intervention, so it is not clear if academic researchers, dietitians, medical professionals or social workers were implementing the other interventions. It is also not clear in several studies, including Srkinar et al. [63] and Khazaal et al. [51], who was collecting any of the data, which could affect participant outcomes (for example, if the patients had an existing relationship with the data collectors) and may be subject to detection bias if assessors were not blind to allocation.

Health outcomes from complex behavioral interventions can be nebulous because multiple factors affect outcomes; however, the RCT format of the studies discussed here improves study rigor [73]. Two studies $[63,65]$ resulted in no statistically significant reduction in metabolic risk factors, with both studies citing small sample sizes and other factors (for example, lack of transportation, motivation) as being possible explanations for these results. Khazaal et al. [51] found limited reduction in weight and body mass index (BMI) in the experimental group. Some subjects' medications were also changed during the study, although the authors 
Table 2 Systematic reviews

\begin{tabular}{|c|c|c|c|}
\hline Authors, year & Title & $\begin{array}{l}\text { \# of studies } \\
\text { reviewed in } \\
\text { article }\end{array}$ & Conclusions \\
\hline $\begin{array}{l}\text { Alvarez-Jiminez, } \\
\text { Hetrick, Gonzalez-Blanch, } \\
\text { Gleeson and McGorry, [15] }\end{array}$ & $\begin{array}{l}\text { Non-pharmacological management of antipsychotic- } \\
\text { induced weight gain: systematic review and } \\
\text { meta-analysis of randomized controlled trials }\end{array}$ & 10 & $\begin{array}{l}\text { Individual and group interventions, cognitive } \\
\text { behavioral therapy and nutritional counseling were } \\
\text { more effective than treatment as usual. }\end{array}$ \\
\hline $\begin{array}{l}\text { Bradshaw, Lovell and } \\
\text { Harris, [16] }\end{array}$ & $\begin{array}{l}\text { Healthy living interventions and schizophrenia: a } \\
\text { systematic review }\end{array}$ & 16 & $\begin{array}{l}\text { Inconclusive based on poor quality of studies } \\
\text { reviewed. }\end{array}$ \\
\hline $\begin{array}{l}\text { Cabassa, Ezell and Lewis- } \\
\text { Fernandez, [67] }\end{array}$ & $\begin{array}{l}\text { Lifestyle interventions for adults with serious } \\
\text { mental illness: a systematic literature review }\end{array}$ & 23 & $\begin{array}{l}\text { Behavioral interventions generally showed } \\
\text { improvement in metabolic syndrome risk factors }\end{array}$ \\
\hline $\begin{array}{l}\text { Caemmerer, Correll and } \\
\text { Maayan, [68] }\end{array}$ & $\begin{array}{l}\text { Acute and maintenance effects of non-pharmacological } \\
\text { interventions for antipsychotic induced weight gain and } \\
\text { metabolic abnormalities: a meta-analytic comparison of } \\
\text { randomized controlled trials }\end{array}$ & 18 & $\begin{array}{l}\text { Behavioral interventions effectively prevented and } \\
\text { reduced weight gain in outpatients agreeing to } \\
\text { participate in trials. Nutritional and cognitive } \\
\text { behavioral interventions were effective. }\end{array}$ \\
\hline $\begin{array}{l}\text { Cimo,Stergiopoulis, } \\
\text { Cheng, Bonato and } \\
\text { Dewa, [69] }\end{array}$ & $\begin{array}{l}\text { Effective lifestyle interventions to improve type } 2 \\
\text { diabetes self-management }\end{array}$ & 4 & $\begin{array}{l}\text { Diabetes education is effective when it includes } \\
\text { diet and exercise and design should address } \\
\text { cognition, motivation and weight gain }\end{array}$ \\
\hline $\begin{array}{l}\text { Faulkner, Soundy and } \\
\text { Lloyd, [17] }\end{array}$ & $\begin{array}{l}\text { Schizophrenia and weight management: a } \\
\text { systematic review of interventions to control } \\
\text { weight }\end{array}$ & 16 & $\begin{array}{l}\text { All behavioral interventions produced small } \\
\text { reductions in, or maintenance of, weight. }\end{array}$ \\
\hline $\begin{array}{l}\text { Gabriele, Dubert and } \\
\text { Reeves, [18] }\end{array}$ & $\begin{array}{l}\text { Efficacy of behavioural interventions in managing } \\
\text { atypical antipsychotic weight gain }\end{array}$ & 16 & $\begin{array}{l}\text { When behavioral interventions were initiated at } \\
\text { the start of atypical antipsychotic (AAP) treatment, } \\
\text { amount of weight gain was decreased. When } \\
\text { initiated after the start of AAP treatment, weight } \\
\text { loss was achieved. Insulin regulation and A1c } \\
\text { (metabolic syndrome risk factors) were also } \\
\text { improved. }\end{array}$ \\
\hline $\begin{array}{l}\text { Megna, Schwartz, Siddiqui } \\
\text { and Rojas, [19] }\end{array}$ & $\begin{array}{l}\text { Obesity in adults with serious and persistent } \\
\text { mental illness: a review of postulated mechanisms } \\
\text { and current interventions }\end{array}$ & 71 & $\begin{array}{l}\text { Non-pharmacological interventions are promising, } \\
\text { but only show low to medium effect size. }\end{array}$ \\
\hline Papanastasiou, [20] & $\begin{array}{l}\text { Interventions for the metabolic syndrome in } \\
\text { schizophrenia: a review }\end{array}$ & 15 & $\begin{array}{l}\text { Behavioral interventions showed benefit, but study } \\
\text { design (non-RCT) did not prove one intervention } \\
\text { superior to another. }\end{array}$ \\
\hline Roberts and Bailey, [21] & $\begin{array}{l}\text { Incentives and barriers to lifestyle interventions for } \\
\text { people with severe mental illness: a narrative } \\
\text { synthesis of quantitative, qualitative and mixed } \\
\text { methods studies }\end{array}$ & 14 & $\begin{array}{l}\text { No studies identified that specifically focus on } \\
\text { incentives and barriers }\end{array}$ \\
\hline $\begin{array}{l}\text { Tosh. Clifton, Mala and } \\
\text { Bachner, [70] }\end{array}$ & $\begin{array}{l}\text { Physical health care monitoring for people with } \\
\text { serious mental illness }\end{array}$ & 0 & $\begin{array}{l}\text { No studies identified that specifically focus on } \\
\text { incentives and barriers. }\end{array}$ \\
\hline $\begin{array}{l}\text { Tosh, Clifton and } \\
\text { Bachner, [22] }\end{array}$ & $\begin{array}{l}\text { General physical health advice for people with } \\
\text { serious mental illness }\end{array}$ & 6 & $\begin{array}{l}\text { Health advice could lead to greater access of } \\
\text { services but ineffective advice may be a waste of } \\
\text { resources. }\end{array}$ \\
\hline \multirow[t]{2}{*}{$\begin{array}{l}\text { Werneke, Taylor, Sanders } \\
\text { and Wessely, [23] }\end{array}$} & $\begin{array}{l}\text { Behavioral management of antipsychotic-induced } \\
\text { weight gain: a review }\end{array}$ & 12 & $\begin{array}{l}\text { No RCTs identified, but interventions appear to be } \\
\text { effective. }\end{array}$ \\
\hline & Total & 221 & \\
\hline
\end{tabular}

used statistical methods to account for the possible impact of these changes [51]. McKibbin et al. [56] and Kwon et al. [53] reported significant reductions in metabolic syndrome risk factors (weight, BMI) as a result of their interventions. Kwon et al. [53] also observed significant weight loss in the control group, which suggests possible threats to internal validity in the design. These authors do note that several members of the experimental group lost a greater percentage of body weight than anyone in the control group.

\section{Conclusions}

The authors were unable to identify rigorous, primary care-based interventions to address physical illness among individuals with mental illness. As the literature expands to include primary care-based interventions, additional systematic reviews and meta-analyses are warranted to assess effectiveness in this setting. Systematic reviews of high-quality RCTs are the most rigorous form of effectiveness research, as single RCTs can have weak designs or biased results [73]. Quality assurance protocols, such as 


\begin{tabular}{|c|c|c|c|c|c|}
\hline Authors, year & Title & Setting & Description of intervention & $\begin{array}{l}\text { Length of } \\
\text { intervention }\end{array}$ & $\begin{array}{l}\text { Appropriate } \\
\text { for primary } \\
\text { care }\end{array}$ \\
\hline Brar et al., [42] & $\begin{array}{l}\text { Effects of behavioral therapy on weight loss in overweight and } \\
\text { obese patients with schizophrenia or schizoaffective disorder }\end{array}$ & Mental health & Manual-based behavioral techniques for weight loss & 14 weeks & Yes \\
\hline $\begin{array}{l}\text { Brown, Goetz, Van Sciver, } \\
\text { Sullivan and Hamera, [43] }\end{array}$ & A psychiatric rehabilitation approach to weight loss & Mental health & $\begin{array}{l}\text { Goal setting, social support, skills training, more } \\
\text { frequent visits with providers, meal replacements }\end{array}$ & 12 weeks & No \\
\hline $\begin{array}{l}\text { Chafetz, White, Collins-Bride, } \\
\text { Cooper and Nickens, [45] }\end{array}$ & $\begin{array}{l}\text { Clinical trial of wellness training: health promotion for severely } \\
\text { mentally ill adults }\end{array}$ & $\begin{array}{l}\text { Short term } \\
\text { residential } \\
\text { treatment }\end{array}$ & $\begin{array}{l}\text { Promoting individual skills in self-management of } \\
\text { illness }\end{array}$ & 12 months & No \\
\hline $\begin{array}{l}\text { Evans, Newton and } \\
\text { Higgins, [46] }\end{array}$ & $\begin{array}{l}\text { Nutritional intervention to prevent weight gain in patients } \\
\text { commenced on olanzapine: a randomized controlled trial }\end{array}$ & Mental health & Nutrition education sessions & 12 weeks & No \\
\hline $\begin{array}{l}\text { Fosberg, Bjorkman, } \\
\text { Sandman and } \\
\text { Sandlund, [47] }\end{array}$ & $\begin{array}{l}\text { Physical health - a cluster randomized controlled lifestyle } \\
\text { intervention among persons with a psychiatric disability and their } \\
\text { staff }\end{array}$ & $\begin{array}{l}\text { Residential } \\
\text { mental health }\end{array}$ & $\begin{array}{c}\text { Curriculum including motivation, food content, stress } \\
\text { and fitness }\end{array}$ & 12 months & No \\
\hline Jean-Baptiste et al., [48] & $\begin{array}{l}\text { A pilot study of a weight management program with food } \\
\text { provision in schizophrenia }\end{array}$ & Mental health & $\begin{array}{l}\text { Weekly group sessions w/dietitian and psychiatrist, } \\
\text { pedometers and food (or reimbursement) provided, } \\
\text { individual nutrition support, grocery store visit }\end{array}$ & 16 weeks & No \\
\hline Khazaal et al., [51] & $\begin{array}{l}\text { Cognitive behavioral therapy for weight gain associated with } \\
\text { antipsychotic drugs }\end{array}$ & Mental health & Cognitive behavioral therapy & 12 weeks & Yes \\
\hline Kilbourne et al., [52] & $\begin{array}{l}\text { Improving medical and psychiatric outcomes among individuals } \\
\text { with bipolar disorder: a randomized controlled trial }\end{array}$ & Mental health & $\begin{array}{l}\text { Self-management sessions on bipolar disorder, } \\
\text { promotion of provider engagement, education } \\
\text { related to cardiovascular disease }\end{array}$ & 4 weeks & Yes \\
\hline Kwon et al., [53] & $\begin{array}{l}\text { Weight management program for treatment-emergent weight } \\
\text { gain in olanzapine-treated patients with schizophrenia or schi- } \\
\text { zoaffective disorder: a 12-week randomized controlled trial }\end{array}$ & Mental health & $\begin{array}{l}\text { Educational program with food diary, nutrition } \\
\text { education, exercise management }\end{array}$ & 12 weeks & Yes \\
\hline Mauri et al., [55] & $\begin{array}{l}\text { A psychoeducational program for weight loss in patients who } \\
\text { have experienced weight gain during antipsychotic treatment } \\
\text { with olanzapine }\end{array}$ & Mental health & $\begin{array}{l}\text { Weekly psycho-educational meetings emphasizing } \\
\text { weight loss with personalized diet plans }\end{array}$ & 24 weeks & No \\
\hline McKibbin et al., [56] & $\begin{array}{l}\text { A lifestyle intervention for older schizophrenia patients with } \\
\text { diabetes mellitus: a randomized controlled trial }\end{array}$ & $\begin{array}{l}\text { Residential } \\
\text { mental health }\end{array}$ & $\begin{array}{c}\text { Diabetes Awareness and Rehabilitation Training } \\
\text { (DART) }\end{array}$ & 24 weeks & Yes \\
\hline Mcreadie et al., [71] & $\begin{array}{l}\text { Dietary improvement in ppl with schizophrenia: randomized } \\
\text { controlled trial }\end{array}$ & $\begin{array}{l}\text { Residential } \\
\text { mental health }\end{array}$ & $\begin{array}{l}\text { Giving fruit, veggies and meal planning to patients } \\
\text { (vs. fruit/vegetables alone) }\end{array}$ & 6 months & No \\
\hline Poulin et al., 2007 [61] & $\begin{array}{l}\text { Management of antipsychotic induced weight gain: prospective } \\
\text { naturalistic study of the effectiveness of a supervised exercise } \\
\text { programme }\end{array}$ & Mental health & $\begin{array}{c}\text { Education, physical education counseling and } \\
\text { exercise }\end{array}$ & 18 months & No \\
\hline Rotatori, Fox and Wicks, [62] & $\begin{array}{l}\text { Weight loss with psychiatric residents in a behavioral self-control } \\
\text { program }\end{array}$ & $\begin{array}{l}\text { Inpatient } \\
\text { mental health }\end{array}$ & Behavior therapy & 14 weeks & No \\
\hline $\begin{array}{l}\text { Skrinar, Huxley, Hutchinson, } \\
\text { Menninger and Glew, [63] }\end{array}$ & $\begin{array}{l}\text { The role of a fitness intervention on people with serious } \\
\text { psychiatric disabilities }\end{array}$ & Mental health & Exercise, weekly education seminars & 12 weeks & Yes \\
\hline Weber and Wyne, [65] & $\begin{array}{l}\text { A cognitive behavioral group intervention for weight loss in } \\
\text { patients treated with atypical antipsychotics }\end{array}$ & Mental health & $\begin{array}{c}\text { Based on Diabetes Prevention Project (DPP) program } \\
\text { to prevent diabetes }\end{array}$ & 16 weeks & Yes \\
\hline
\end{tabular}


Table 4 Methodological quality of studies appropriate for primary care

\begin{tabular}{|c|c|c|c|c|c|c|c|c|c|c|}
\hline Author, date & $\begin{array}{l}\text { Type of } \\
\text { study }\end{array}$ & $\begin{array}{l}\text { Sample } \\
\text { size }\end{array}$ & $\begin{array}{l}\text { Power } \\
\text { analysis } \\
\text { described }\end{array}$ & $\begin{array}{l}\text { How } \\
\text { participant } \\
\text { characteristics } \\
\text { described }\end{array}$ & $\begin{array}{l}\text { Review } \\
\text { board } \\
\text { approved }\end{array}$ & $\begin{array}{l}\text { Randomization } \\
\text { process } \\
\text { described }\end{array}$ & Comparator & $\begin{array}{l}\text { Blinding } \\
\text { described }\end{array}$ & $\begin{array}{l}\text { Evidence base for } \\
\text { intervention } \\
\text { described }\end{array}$ & $\begin{array}{l}\text { Statistical analysis } \\
\text { described }\end{array}$ \\
\hline Brar et al., [42] & $\mathrm{RCT}$ & 71 & Yes & Narrative & Yes & No & $\begin{array}{l}\text { Monthly weight checks } \\
\text { and encouragement of } \\
\text { weight loss }\end{array}$ & No & $\begin{array}{l}\text { Yes; table with } \\
\text { previous studies }\end{array}$ & $\begin{array}{l}\text { Yes (paired } t \text {-tests, logistic } \\
\text { regression, ANCOVA, } \\
\text { Cochran-mantel-Haenszel) }\end{array}$ \\
\hline Khazaal et al., [51] & $\mathrm{RCT}$ & 61 & No & Table & Yes & No & $\begin{array}{l}\text { Control group with brief } \\
\text { nutritional education }\end{array}$ & No & $\begin{array}{l}\text { Yes; previous "Apple } \\
\text { Pie" study }\end{array}$ & $\begin{array}{l}\text { Yes (t-tests, Chi-square, } \\
\text { MANOVA, MANCOVA, } \\
\text { Fisher's exact significance } \\
\text { tests, Cochran's Q test) }\end{array}$ \\
\hline Kwon et al., [53] & $\mathrm{RCT}$ & 48 & Yes & Table & Yes & No & $\begin{array}{l}\text { Routine care with verbal } \\
\text { diet and weight management } \\
\text { recommendations. Control } \\
\text { group also given food and } \\
\text { exercise diaries. }\end{array}$ & No & No & Yes ( $t$-test and ANCOVA) \\
\hline McKibbin et al., [56] & $\mathrm{RCT}$ & 64 & No & Table & Yes & No & $\begin{array}{l}\text { Usual care with three health- } \\
\text { related brochures distributed }\end{array}$ & No & $\begin{array}{l}\text { Yes; previous DART } \\
\text { study and theoretical } \\
\text { orientation }\end{array}$ & $\begin{array}{l}\text { Yes (ANOVA, t-tests, chi- } \\
\text { square) }\end{array}$ \\
\hline $\begin{array}{l}\text { Skrinar, Huxley, } \\
\text { Hutchison, } \\
\text { Menninger and } \\
\text { Glew, [63] }\end{array}$ & $\mathrm{RCT}$ & 20 & No & Table & Yes & No & Waiting list control group & No & $\begin{array}{l}\text { Yes; cites literature } \\
\text { about role of exercise } \\
\text { in weight } \\
\text { management }\end{array}$ & Yes (ANOVA) \\
\hline $\begin{array}{l}\text { Weber and } \\
\text { Wyne, [65] }\end{array}$ & $\mathrm{RCT}$ & 17 & $\begin{array}{l}\text { No (pilot } \\
\text { study) }\end{array}$ & Table & Yes & No & $\begin{array}{l}\text { Control group received } \\
\text { treatment as usual and } \\
\text { were weighed every four } \\
\text { weeks. }\end{array}$ & Yes & $\begin{array}{l}\text { Yes; previous Diabetes } \\
\text { Prevention Project }\end{array}$ & $\begin{array}{l}\text { Yes (t-testt-test, statistical } \\
\text { significance set at } 0.05)\end{array}$ \\
\hline
\end{tabular}


the CLEAR NPT checklist for non-pharmacological trials [74], which provides a checklist for components of quality in a study, should be incorporated into future studies in this area to provide standardized guidelines for making effectiveness claims.

Adequate reporting of interventional content and components is also essential to the expansion of literature in this subject area and groups, such as the Workgroup for Intervention Development and Evaluation Research (WIDER), have developed suggestions for intervention reporting (http://interventiondesign.co.uk). WIDER advocates for the successful adoption of behavior change interventions and the expansion of CONSORT (www.consortstatement.org) and APA guidelines to allow for improved reporting of these interventions. In behavioral intervention research, theories regarding the specific mechanism of change within an intervention should be utilized during the development of the intervention and should be described in the final report [36].

Social work researchers and direct service social workers in health care settings have an opportunity to design and implement high-quality behavioral and educational programs for individuals with major psychotic and/or affective disorders using the criteria described above. Social workers are among the few professionals in health care settings who have the skills and opportunity to work closely with the patients most in need of healthrelated behavior change interventions, as they are generally able to spend more time with patients in health care settings and have access to medical information in collocated health and mental health settings. Interventions to decrease metabolic syndrome risk factors have been demonstrated to be successful in mental health settings, but the primary service in mental health settings is mental health. Primary care-based interventions are important for conveying the message that the focus is on physical health, even if the population is comprised of individuals with major psychotic and/or affective disorders. Social workers or social work researchers participating in health-focused interventions that do not follow published guidelines for research and reporting of RCTs are missing an important opportunity to enhance systematic reviews of literature about this population.

\section{Additional file}

Additional file 1: PRISMA diagram for BMC. PRISMA 2009 Flow Diagram. PRISMA diagram of studies excluded.

\section{Abbreviations}

AAP: Atypical antipsychotic medication; BMI: Body mass index; DART: Diabetes Awareness and Rehabilitation Training; RCT: Randomized control trial.

\section{Competing interests}

The authors declare that they have no competing interests.

\section{Authors' contributions}

CN conceived of the study, developed the search terms, conducted the literature search, reviewed studies and drafted the manuscript. SJ served as the second reviewer, developed the tables and assisted with drafting the manuscript. CN and SJ together edited the manuscript. Both authors read and approved the final manuscript.

\section{Acknowledgements}

The authors would like to acknowledge the contributions of Timothy Sharma, who assisted with study design and acquisition of data. This contribution was not funded by any outside source.

\section{Author details}

${ }^{1}$ College of Social \& Behavioral Sciences and Social Work, Eastern Washington University, 208 Senior Hall, Cheney, WA 99004, USA.

2Department of Epidemiology/Biostatistics, George Washington University, School of Public Health, 2100 W. Pennsylvania Ave., 8th Floor, Washington, DC 20037, USA.

Received: 3 June 2013 Accepted: 5 December 2013

Published: 27 December 2013

\section{References}

1. Bobes J, Arango C, Garcia-Garcia M, Rejas J: Healthy lifestyle habits and 10-year cardiovascular risk in schizophrenia spectrum disorders: an analysis of the impact of smoking tobacco in the CLAMORS schizophrenia cohort. Schizophr Res 2010, 119:101-109.

2. Muir-Cochrane E: Medical co-morbidity risk factors and barriers to care for people with schizophrenia. J Psychiatr Ment Health Nurs 2006, 13:447-452.

3. Osborn DP, Wright CA, Levy G, King MB, Deo R, Nazareth I: Relative risk of diabetes, dyslipidaemia, hypertension and the metabolic syndrome in people with severe mental illnesses: systematic review and metaanalysis. BMC Psychiatry 2008, 8:84.

4. Dunbar JA, Reddy P, Davis-Lameloise N, Philpot B, Laatikainen T, Kilkkinen A, Bunker SJ, Best JD, Vartiainen E, Kai Lo S, Janus ED: Depression: an important comorbidity with metabolic syndrome in a general population. Diabetes Care 2008, 31:2368-2373.

5. Wassertheil-Smoller S, Shumaker S, Ockene J, Talavera GA, Greenland P, Cochrane B, Robbins J, Aragaki A, Dunbar-Jacob J: Depression and cardiovascular sequelae in postmenopausal women. The Women's Health Initiative (WHI). Arch Intern Med 2004, 164:289-298.

6. Cardenas J, Frye MA, Marusak SL, Levander EM, Chirichigno JW, Lewis S, Nakelsky S, Hwang S, Mintz J, Altshuler LL: Modal subcomponents of metabolic syndrome in patients with bipolar disorder. J Affect Disord 2008, 106:91-97.

7. Salvi V, D'Ambrosio V, Rosso G, Bogetto F, Maina G: Age-specific prevalence of metabolic syndrome in Italian patients with bipolar disorder. Psychiatry Clin Neurosci 2011, 65:47-54.

8. Correll CU, Frederickson AM, Kane JM, Manu P: Equally increased risk for metabolic syndrome in patients with bipolar disorder and schizophrenia treated with second-generation antipsychotics. Bipolar Disord 2008, 10:788-797.

9. McEvoy JP, Meyer JM, Goff DC, Nasrallah HA, Davis SM, Sullivan L, Meltzer HY, Hsiao J, Scott ST, Lieberman JA: Prevalence of the metabolic syndrome in patients with schizophrenia: baseline results from the Clinical Antipsychotic Trials of Intervention Effectiveness (CATIE) schizophrenia trial and comparison with national estimates from NHANES III. Schizophr Res 2005, 80:19-32.

10. Tarricone I, Casoria M, Gozzi BF, Grieco D, Menchetti M, Serretti A, Ujkaj M, Pastorelli F, Berardi D: Metabolic risk factor profile associated with use of second generation antipsychotics: a cross sectional study in a Community Mental Health Centre. BMC Psychiatry 2006, 6:11.

11. Bonnet F, Irving K, Terra JL, Nony P, Berthezene F, Moulin P: Anxiety and depression are associated with unhealthy lifestyle in patients at risk of cardiovascular disease. Atherosclerosis 2005, 178:339-344.

12. Pack S: Poor physical health and mortality in patients with schizophrenia. Nurs Stand 2009, 23:41-45. 
13. Softic R, Sutovic A, Avdibegovic E: Hazardous lifestyles in patients with schizophrenia treated with antipsychotics: results of the Bosnian clinical study. Eur Psychiatry 2009, 24:S1202.

14. Molarius $A$, Berglund $K$, Eriksson $C$, Eriksson HG, Lindén-Boström $M$, Nordström E, Persson C, Sahlqvist L, Starrin B, Ydreborg B: Mental health symptoms in relation to socio-economic conditions and lifestyle factorsa population-based study in Sweden. BMC Public Health 2009, 9:302.

15. Alvarez-Jimenez M, Hetrick SE, Gonzalez-Blanch C, Gleeson JF, McGorry PD: Non-pharmacological management of antipsychotic-induced weight gain: systematic review and meta-analysis of randomised controlled trials. Br J Psychiatry 2008, 193:101-107.

16. Bradshaw $T$, Lovell $K$, Harris N: Healthy living interventions and schizophrenia: a systematic review. J Adv Nurs 2005, 49:634-654.

17. Faulkner G, Soundy AA, Lloyd K: Schizophrenia and weight management: a systematic review of interventions to control weight. Acta Psychiatr Scand 2003, 108:324-332.

18. Gabriele JM, Dubbert PM, Reeves RR: Efficacy of behavioural interventions in managing atypical antipsychotic weight gain. Obes Rev 2009, 10:442-455.

19. Megna JL, Schwartz TL, Siddiqui UA, Herrera RM: Obesity in adults with serious and persistent mental illness: a review of postulated mechanisms and current interventions. Ann Clin Psychiatry 2011, 23:131-140.

20. Papanastasiou E: Interventions for the metabolic syndrome in schizophrenia: a review. Ther Adv Endocrinol Metab 2012, 3:141-162.

21. Roberts SH, Bailey JE: Incentives and barriers to lifestyle interventions for people with severe mental illness: a narrative synthesis of quantitative, qualitative and mixed methods studies. J Adv Nurs 2011, 67:690-708.

22. Tosh G, Clifton A, Bachner M: General physical health advice for people with serious mental illness. Schizophr Bull 2011, 37:671-673.

23. Werneke U, Taylor D, Sanders TA, Wessely S: Behavioural management of antipsychotic-induced weight gain: a review. Acta Psychiatr Scand 2003, 108:252-259.

24. Druss BG, Rohrbaugh RM, Levinson CM, Rosenheck RA: Integrated medical care for patients with serious psychiatric illness: a randomized trial. Arch Gen Psychiatry 2001, 58:861-868.

25. Yoong SL, Carey M, Sanson-Fisher R, Grady A: A systematic review of behavioural weight-loss interventions involving primary-care physicians in overweight and obese primary-care patients (1999-2011). Public Health Nutr 2013, 16:2083-2099.

26. Brown l: Primary care interventions for obesity: behavioural support, whether delivered remotely or in person, facilitates greater weight loss over 2 years than self-directed weight loss. Evid Based Nurs 2012, 15:89-90.

27. Xiao L, Yank V, Wilson SR, Lavori PW, Ma J: Two-year weight-loss maintenance in primary care-based Diabetes Prevention Program lifestyle interventions. Nutr Diabetes 2013, 3:e76.

28. Bennett GG, Foley P, Levine E, Whiteley J, Askew S, Steinberg DM, Batch B, Greaney ML, Miranda H, Wroth TH, Holder MG, Emmons KM, Puleo E: Behavioral treatment for weight gain prevention among black women in primary care practice: a randomized clinical trial. JAMA Intern Med 2013, 173:1770-1777.

29. Vetter ML, Wadden TA, Chittams J, Diewald LK, Panigrahi E, Volger S, Sarwer $\mathrm{DB}$, Moore RH: Effect of lifestyle intervention on cardiometabolic risk factors: results of the POWER-UP trial. Int J Obes (Lond) 2013, 37(Suppl 1):S19-S24.

30. Serrano-Blanco A, Palao DJ, Luciano JV, Pinto-Meza A, Lujan L, Fernandez A, Roura P, Bertsch J, Mercader M, Haro JM: Prevalence of mental disorders in primary care: results from the diagnosis and treatment of mental disorders in primary care study (DASMAP). Soc Psychiatry Psychiatr Epidemiol 2010, 45:201-210.

31. Das AK, Olfson M, Gameroff MJ, Pilowsky DJ, Blanco C, Feder A, Gross R, Neria Y, Lantigua R, Shea S, Weissman MM: Screening for bipolar disorder in a primary care practice. JAMA 2005, 293:956-963.

32. Blount A: Integrated Primary Care: the Future of Medical and Mental Health Collaboration. New York, NY: W.W. Norton and Co; 1998.

33. Roca M, Gili M, Garcia-Garcia M, Salva J, Vives M, Garcia CJ, Comas A: Prevalence and comorbidity of common mental disorders in primary care. J Affect Disord 2009, 119:52-58.

34. Fernandez A, Saameno JA, Pinto-Meza A, Luciano JV, Autonell J, Palao D, Salvador-Carulla L, Campayo JG, Haro JM, Serrano A: Burden of chronic physical conditions and mental disorders in primary care. Br J Psychiatry 2010, 196:302-309.

35. Cashin CE, Adams N, Handon B: Excess non-psychiatric hospitalization among Medi-Cal beneficiaries with serious mental illness in California. Sacramento: California Department of Health Care Services; 2008.
36. Michie S, Fixsen D, Grimshaw JM, Eccles MP: Specifying and reporting complex behaviour change interventions: the need for a scientific method. Implement Sci 2009, 4:40.

37. Nover $\mathrm{CH}$ : Mental health in primary care: perceptions of augmented care for individuals with serious mental illness. Soc Work Health Care 2013, 52:656-668.

38. Alvarez-Jimenez M, Gonzalez-Blanch C, Vazquez-Barquero JL, Perez-Iglesias R, Martinez-Garcia O, Perez-Pardal T, Ramirez-Bonilla ML, Crespo-Facorro B: Attenuation of antipsychotic-induced weight gain with early behavioral intervention in drug-naive first-episode psychosis patients: a randomized controlled trial. J Clin Psychiatry 2006, 67:1253-1260.

39. Attux C, Martini LC, Araujo CM, Roma AM, Reis AF, Bressan RA: The effectiveness of a non-pharmacological intervention for weight gain management in severe mental disorders: results from a national multicentric study. Rev Bras Psiquiatr 2011, 33:117-121.

40. Ball MP, Coons VB, Buchanan RW: A program for treating olanzapinerelated weight gain. Psychiatr Serv 2001, 52:967-969.

41. Bradshaw T, Lovell K, Bee P, Campbell M: The development and evaluation of a complex health education intervention for adults with a diagnosis of schizophrenia. J Psychiatr Ment Health Nurs 2010, 17:473-486.

42. Brar JS, Ganguli R, Pandina G, Turkoz I, Berry S, Mahmoud R: Effects of behavioral therapy on weight loss in overweight and obese patients with schizophrenia or schizoaffective disorder. J Clin Psychiatry 2005, 66:205-212

43. Brown C, Goetz J, Van Sciver A, Sullivan D, Hamera E: A psychiatric rehabilitation approach to weight loss. Psychiatr Rehabil J 2006, 29:267-273.

44. Centorrino F, Wurtman JJ, Duca KA, Fellman VH, Fogarty KV, Berry JM, Guay DM, Romeling M, Kidwell J, Cincotta SL, Baldessarini RJ: Weight loss in overweight patients maintained on atypical antipsychotic agents. Int J Obes (Lond) 2006, 30:1011-1016.

45. Chafetz L, White M, Collins-Bride G, Cooper BA, Nickens J: Clinical trial of wellness training: health promotion for severely mentally ill adults. J Nerv Ment Dis 2008, 196:475-483.

46. Evans S, Newton R, Higgins S: Nutritional intervention to prevent weight gain in patients commenced on olanzapine: a randomized controlled trial. Aust N Z J Psychiatry 2005, 39:479-486.

47. Forsberg KA, Bjorkman T, Sandman PO, Sandlund M: Physical health-a cluster randomized controlled lifestyle intervention among persons with a psychiatric disability and their staff. Nord J Psychiatry 2008, 62:486-495.

48. Jean-Baptiste M, Tek C, Liskov E, Chakunta UR, Nicholls S, Hassan AQ, Brownell KD, Wexler BE: A pilot study of a weight management program with food provision in schizophrenia. Schizophr Res 2007, 96:198-205.

49. Jones B, Basson BR, Walker DJ, Crawford AM, Kinon BJ: Weight change and atypical antipsychotic treatment in patients with schizophrenia. J Clin Psychiatry 2001, 62(Suppl 2):41-44.

50. Kalarchian MA, Marcus MD, Levine MD, Haas GL, Greeno CG, Weissfeld LA, Qin L: Behavioral treatment of obesity in patients taking antipsychotic medications. J Clin Psychiatry 2005, 66:1058-1063.

51. Khazaal Y, Fresard E, Rabia S, Chatton A, Rothen S, Pomini V, Grasset F, Borgeat F, Zullino D: Cognitive behavioural therapy for weight gain associated with antipsychotic drugs. Schizophr Res 2007, 91:169-177.

52. Kilbourne AM, Post EP, Nossek A, Drill L, Cooley S, Bauer MS: Improving medical and psychiatric outcomes among individuals with bipolar disorder: a randomized controlled trial. Psychiatr Serv 2008, 59:760-768.

53. Kwon JS, Choi JS, Bahk WM, Yoon KC, Hyung KC, Chul SY, Park BJ, Geun OC: Weight management program for treatment-emergent weight gain in olanzapine-treated patients with schizophrenia or schizoaffective disorder: a 12-week randomized controlled clinical trial. J Clin Psychiatry 2006, 67:547-553.

54. Littrell KH, Hilligoss NM, Kirshner CD, Petty RG, Johnson CG: The effects of an educational intervention on antipsychotic-induced weight gain. J Nurs Scholarsh 2003, 35:237-241.

55. Mauri M, Simoncini M, Castrogiovanni S, lovieno N, Cecconi D, Dell'Agnello G, Quadrigli M, Rossi A, Donda P, Fagiolini A, Cassano GB: A psychoeducational program for weight loss in patients who have experienced weight gain during antipsychotic treatment with olanzapine. Pharmacopsychiatry 2008, 41:17-23.

56. McKibbin $\mathrm{CL}$, Patterson TL, Norman G, Patrick K, Jin H, Roesch S, Mudaliar S, Barrio C, O'Hanlon K, Griver K, Sirkin A, Jeste DV: A lifestyle intervention for older schizophrenia patients with diabetes mellitus: a randomized controlled trial. Schizophr Res 2006, 86:36-44. 
57. Ohlsen RI, Treasure J, Pilowsky LS: A dedicated nurse-led service for antipsychotic-induced weight gain: an evaluation. Psychiatrist 2004, 28:164-166.

58. Park T, Usher K, Foster K: Description of a healthy lifestyle intervention for people with serious mental illness taking second-generation antipsychotics. Int J Ment Health Nurs 2011, 20:428-437.

59. Pendlebury J, Bushe CJ, Wildgust HJ, Holt Rl: Long-term maintenance of weight loss in patients with severe mental illness through a behavioural treatment programme in the UK. Acta Psychiatr Scand 2007, 115:286-294.

60. Perlman LM, Cohen JL, Altiere MJ, Brennan JA, Brown SR, Mainka JB, Diroff $C R$ : A multidimensional wellness group therapy program for veterans with comorbid psychiatric and medical conditions. Prof Psychol Res Pract 2010, 41:120-127.

61. Poulin MJ, Chaput JP, Simard V, Vincent P, Bernier J, Gauthier Y, Lanctot G, Saindon J, Vincent A, Gagnon S, Tremblay A: Management of antipsychotic-induced weight gain: prospective naturalistic study of the effectiveness of a supervised exercise programme. Aust N Z J Psychiatry 2007, 41:980-989.

62. Rotatori AF, Fox R, Wicks A: Weight loss with psychiatric residents in a behavioral self control program. Psychol Rep 1980, 46:483-486.

63. Skrinar GS, Huxley NA, Hutchinson DS, Menninger E, Glew P: The role of a fitness intervention on people with serious psychiatric disabilities. Psychiatr Rehabil J 2005, 29:122-127.

64. Vreeland B, Minsky S, Menza M, Rigassio RD, Roemheld-Hamm B, Stern R: A program for managing weight gain associated with atypical antipsychotics. Psychiatr Serv 2003, 54:1155-1157.

65. Weber M, Wyne K: A cognitive/behavioral group intervention for weight loss in patients treated with atypical antipsychotics. Schizophr Res 2006, 83:95-101.

66. Weber $\mathrm{M}$, Colon M, Nelson M: Pilot study of a cognitive behavioral group intervention to prevent further weight gain in Hispanic individuals with schizophrenia. J Am Psychiatr Nurses Assoc 2008, 13:353-359.

67. Cabassa LJ, Ezell JM, Lewis-Fernandez R: Lifestyle interventions for adults with serious mental illness: a systematic literature review. Psychiatr Serv 2010, 61:774-782.

68. Caemmerer J, Correll CU, Maayan L: Acute and maintenance effects of non-pharmacologic interventions for antipsychotic associated weight gain and metabolic abnormalities: a meta-analytic comparison of randomized controlled trials. Schizophr Res 2012, 140:159-168.

69. Cimo A, Stergiopoulos E, Cheng C, Bonato S, Dewa CS: Effective lifestyle interventions to improve type II diabetes self-management for those with schizophrenia or schizoaffective disorder: a systematic review. BMC Psychiatry 2012, 12:24

70. Tosh G, Clifton A, Mala S, Bachner M: Physical health care monitoring for people with serious mental illness. Cochrane Database Syst Rev 2010, 3:CD008298.

71. McCreadie RG, Kelly C, Connolly M, Williams S, Baxter G, Lean M, Paterson $J R$ : Dietary improvement in people with schizophrenia: randomised controlled trial. Br J Psychiatry 2005, 187:346-351.

72. Craig P, Dieppe P, Macintyre S, Michie S, Nazareth I, Petticrew M: Developing and evaluating complex interventions: the new Medical Research Council guidance. BMJ 2008, 337:a1655.

73. Torgerson DJ, Torgerson CJ: Designing Randomised Trials in Health, Education and the Social Sciences: An Introduction. New York: Palgrave Macmillan; 2008.

74. Boutron I, Moher D, Tugwell P, Giraudeau B, Poiraudeau S, Nizard R, Ravaud P: A checklist to evaluate a report of a nonpharmacological trial (CLEAR NPT) was developed using consensus. J Clin Epidemiol 2005, 58:1233-1240.

doi:10.1186/2046-4053-2-116

Cite this article as: Nover and Jackson: Primary care-based educational interventions to decrease risk factors for metabolic syndrome for adults with major psychotic and/or affective disorders: a systematic review. Systematic Reviews 2013 2:116.

\section{Submit your next manuscript to BioMed Central and take full advantage of:}

- Convenient online submission

- Thorough peer review

- No space constraints or color figure charges

- Immediate publication on acceptance

- Inclusion in PubMed, CAS, Scopus and Google Scholar

- Research which is freely available for redistribution

Submit your manuscript at www.biomedcentral.com/submit 